\begin{tabular}{c} 
journal homepage: http://ijiemjournal. uns.ac.rs/ \\
International Journal of Industrial \\
Engineering and Management \\
Volume $13 /$ No $1 /$ March $2022 / 1-7$ \\
\hline
\end{tabular}

Original research article

\title{
The Recommendations for Implementation of Green Public Procurement in Hospitals
}

\author{
N. B. Puspitasaria ${ }^{\star}$, Z. F. Rosyada ${ }^{\text {a }}$, F. I. Habiba ${ }^{\text {, }}$, and A. K. A. Devytasaria \\ a Diponegoro University, Department of Industrial Engineering, Semarang, Indonesia
}

\begin{abstract}
A B STRACT
Every institution running the services needs to procure goods and services in running the activities. The procurement practices not only discuss the quality and value of products but also determine the environmental impact. This study identifies and evaluates factors that affected the application of Green public procurement (GPP) in hospitals and looked at the recommended solutions and response actions. Respondents selected as the object of this study were 34 people involved in the procurement process from several Indonesian government hospitals. In this study, the inhibiting factors of the application of GPP were divided into eight variables with 27 indicators. The analytical method used in this study is the PLS method. The study results indicated that two of the eight indicators significantly affected the implementation of GPP are cost and products.
\end{abstract}

\author{
ARTICLE INFO \\ Article history: \\ Received May 3, 2021 \\ Revised October 27, 2021 \\ Accepted November 19, 2021 \\ Published online December 2, 2021 \\ Keywords: \\ green public procurement; \\ hospital; \\ environmental; \\ government \\ ${ }^{*}$ Corresponding author: \\ Nia Budi Puspitasari \\ niabudipuspitasari@lecturer.undip.ac.id
}

\section{Introduction}

Every agency or institution needs proses procurement of goods and services in carrying out government and private activities. Procurement is a process to comply the supply and demand [1]. In Indonesia, the government procurement process was regulated in Peraturan Presiden Republik Indonesia No. 16 of 2018 and its changes to Peraturan Presiden No. 12 of 2021 on Procurement of Government Goods / Services. This regulation explained that the procurement of government goods/services is a procurement activity of goods/services by the Ministry / Institution / Regional Device financed by the APBN / APBD, whose process from the identification of needs until the handover of work results.
With the development of the world of business, procurement regulation and practices in various worlds continue to be refined towards the best practices and innovations. The development of procurement practices shows that a country's procurement system nationally follows a structured approach to change and capacity building. In line with these developments, policymakers are increasingly clear that procurement can act far more strategically and specifically contribute to reaching goals.

The world's first procurement policy focused on environmental factors was U.S. Government Executive Orders Number 12873: Federal Acquisition, Recycling, and Waste Prevention, adopted in 1993. The Executive Order was kept updated and last updated in 2015 with Executive Order number 13693: Plan- 
ning for Federal Sustainability in the next decade. In addition to the U.S. Government's Executive Order, the Procurement Strategy for Aboriginal Businesses was adopted in 1996, and the Green Procurement Policy was adopted ten years later in Canada. According to the 2017 Global Review survey, almost all European and Asian countries adopted the first sustainable procurement policy between 2001 and 2009. Most countries in Europe approved the National Green Public Procurement Action Plan after 2006, following policy recommendations from the European Commission. Since 2012, many European countries have revised and updated the National Green Public Procurement Action Plan [2].

Green Public Procurement (GPP) is a tool to achieve environmental policy objectives related to climate change, resource use, consumption, and production in procurement activities of goods/services [3]. According to [4] GPP, the process carried out by public authorities to procure goods, services, or projects that minimize environmental impact. GPP is often referred to as environmentally sound procurement [5], sustainable public procurement, [6] environmentally friendly procurement [7], or environmentally oriented public procurement [8].

The GPP has been supported on several policies and strategies in Europe, reflecting that there is potential to encourage the use of more environmentally friendly resources, establish behavioral changes for consumption and production regarding environmental impact, and encourage innovation [2]. One of the publicly owned facilities that are considered to have an essential role in health services is the hospital. The number of hospitals in Indonesia from 2012 to 2019 increased by an average of $4.4 \%$, although in March 2019, there was a slight decrease in the number of hospitals. Based on the growth of hospitals per region, regional 1 is the region with the most hospital growth. In addition, hospitals can be classified based on their ownership of government and private. The number of private hospitals has grown more than the government hospital, with an average growth of $6 \%$. At the same time, the growth of government hospitals is only $2 \%[9]$.

Based on this research on the relationship between [10] sustainable procurement and e-procurement in the public sector, the identification results of 32 studies on green public procurement there are only four conducted in the health sector. This research makes the hospital the object of study of the application of green public procurement.

The main focus in this study is the challenge of implementing green public procurement in hospitals which is considered that the implementation of GPP is still low and unstructured. The study adopted the framework of the conceptual model by Ahsan and Rahman [11] and combined several subcriteria from studies conducted by Oruezabala and Rico [6] as well as Gonzalo and Bovea [12] to evaluate the factors that are challenging in the implementation of GPP in Indonesian hospitals.

The results of interviews with procurement staff from one of the government hospitals in Central Java stated that it has not actively carried out environmentally friendly procurement. Procurement carried out by hospitals is only determined based on financial factors, the need for products, and the level of durability of a product. Hospitals still find it challenging to implement GPP because of the many aspects and need to be considered.

From the explanation, researchers conduct studies that identify variables that influence GPP policies in government hospitals and look for recommendations for appropriate solutions according to those variables. The challenge was divided into eight categories and was broken back down into 27 subcriteria adopted from the researches of Ahsan and Rahman [11], Oruezabala and Rico [6], as well as Gonzalo and Bovea [12].

This study will measure the variables in implementing the GPP policy by the Partial Least Square (PLS) approach. PLS is an equation model Structural Equation Modeling (SEM) based on variants or components. PLS is an alternative approach that is shifting from a covariance-based SEM approach to a variant-based one. Ghozali (2014) explained that PLS is a method of analysis that is soft modeling because it is not based on the assumption of data with the scale of measurement, data distribution, and the number of samples that means the number of samples can be small (below 100 samples) [13].

\section{Materials and methods}

The first step of this research is to determine the variables and indicators of the application of GPP that will be applied to the research object. This research uses the literature study process to refer to scientific journals about GPP to be studied and used to help find the variables and indicators that follow. This study was adopted from the research of Ahsan and Rahman [11], Oruezabala and Rico [6], as well as Gonzalo and Bovea [12], so that eight variables and 27 indicators were formed.

In this study, the application of GPP was mea- 
sured from eight variables, namely GOVT (Government, LSM, Public), ORGN (Organization), KNOW (Knowledge), COST (Organizational Cost), METD (Method), PROD (Product), SUPP (Supplier), and ENV (Environmental Impact), as well as with 27 variable indicators. Variable and the indicator can be seen in table 1 .

After obtaining variables and indicators, the questionnaire was distributed to 34 people who get involved in the procurement process from several Indonesian government hospitals with work experience in the procurement field of at least three years. The questionnaires given by respondents were created using the Likert measurement scale.

The results of the questionnaire answer will be processed using the PLS method with SmartPLS software. PLS is a common method for estimating path models that use latent constructs with multiple indicators [14]. The purpose of PLS is to predict the effect of variable $\mathrm{X}$ on $\mathrm{Y}$ and explain the theoreti- cal relationship between the two variables. PLS is a regression method that can be used for the identification of factors that are a combination of variable $\mathrm{X}$ as an explanation and variable $\mathrm{Y}$ in response [15].

\section{Results}

Based on the relationship between latent variables, namely between the application of GPP and the variables GOVT, ORGN, KNOW, COST, METD, PROD, SUPP, and ENV, a preliminary path diagram is obtained. After evaluating the goodness of fit convergent validity, there is an invalid indicator because of the loading value, 0.7 [16].

From the calculation of loading values, it can be known that there are five invalid indicators, namely GOVT1, GOVT2, ORGN1, COST2, and SUPP1. To correct the invalid indicator to meet the specified criteria, the invalid indicator must be dropped [16]

Table 1. Research Variables

\begin{tabular}{|c|c|c|}
\hline Variable & Code & Variable Indicator \\
\hline \multirow{5}{*}{$\begin{array}{c}\text { Government, LSM, and } \\
\text { Public } \\
\text { (GOVT)[11][6] }\end{array}$} & GOVT1 & Government regulations on green procurement \\
\hline & GOVT2 & Government incentives for green policy \\
\hline & GOVT3 & The degree of legitimacy of green procurement policies \\
\hline & GOVT4 & The level of pressure from the community \\
\hline & GOVT5 & Pressure level from LSM \\
\hline \multirow{3}{*}{$\begin{array}{l}\text { Organization } \\
(\text { ORGN)[11][6] }\end{array}$} & ORGN1 & Executive support in the implementation of green procurement \\
\hline & ORGN2 & Strategic objectives of green procurement \\
\hline & ORGN3 & The number of workers in the field of green procurement \\
\hline \multirow{3}{*}{$\begin{array}{l}\text { Knowledge of } \\
\text { Environmental Issue } \\
(\text { KNOW })[11][6]\end{array}$} & KNOW1 & Knowledge of environmentally friendly policies \\
\hline & KNOW2 & Knowledge of the environmental impact of a product \\
\hline & KNOW3 & Preference for buying environmentally friendly products \\
\hline \multirow{3}{*}{$\begin{array}{l}\text { Cost and Profit } \\
(\text { COST)[11][6] }\end{array}$} & COST1 & Financial support in the implementation of green procurement \\
\hline & COST2 & The cost of finding resources \\
\hline & COST3 & Value of product offerings \\
\hline \multirow{3}{*}{$\begin{array}{c}\text { Method } \\
\text { (METHOD)[12] }\end{array}$} & METD1 & Timely and energy-efficient distribution of material products \\
\hline & METD2 & Location-appropriate, time-efficient, and power-efficient material placement \\
\hline & METD3 & Schedule to check product availability \\
\hline \multirow{4}{*}{$\begin{array}{l}\text { Product } \\
\text { (PROD)[12] }\end{array}$} & PROD1 & Eco-label certified products \\
\hline & PROD2 & Product packaging can be recycled or reused \\
\hline & PROD3 & Use of recycled products \\
\hline & PROD4 & Level of use of hazardous materials \\
\hline \multirow{4}{*}{$\begin{array}{l}\text { Supplier Problems } \\
\text { (SUPP)[11][6] }\end{array}$} & SUPP1 & Level of collaboration with suppliers \\
\hline & SUPP2 & Supplier's level of knowledge about environmentally friendly products \\
\hline & SUPP3 & Availability of suppliers of environmentally friendly products \\
\hline & SUPP4 & Supplier commitment \\
\hline \multirow{3}{*}{$\begin{array}{l}\text { Environment } \\
(\text { ENV)[12] }\end{array}$} & ENV1 & Level of energy consumption \\
\hline & ENV2 & Waste income \\
\hline & ENV3 & Waste management \\
\hline
\end{tabular}


and generate a new path diagram. Figure 1 is a diagram of the new outline path, where the blue circle shows the variable and the yellow box shows the variable indicator of the implementation of the GPP with each loading value.

The next step of the evaluation of the goodness of fit is discriminant validity and composite reliability. Table 2 depicts the results. for the GPP Implementation construct. This means that the value indicates that the variables GOVT, ORGN, KNOW, COST, METD, PROD, SUPP, and ENV can explain the GPP application variant of about $71.4 \%$; the rest is influenced by other factors not discussed in the study. In addition, the evaluation of the model can be done by looking at the value of $\mathrm{Q}^{2}$. From the results of the calculation, the $\mathrm{Q} 2$

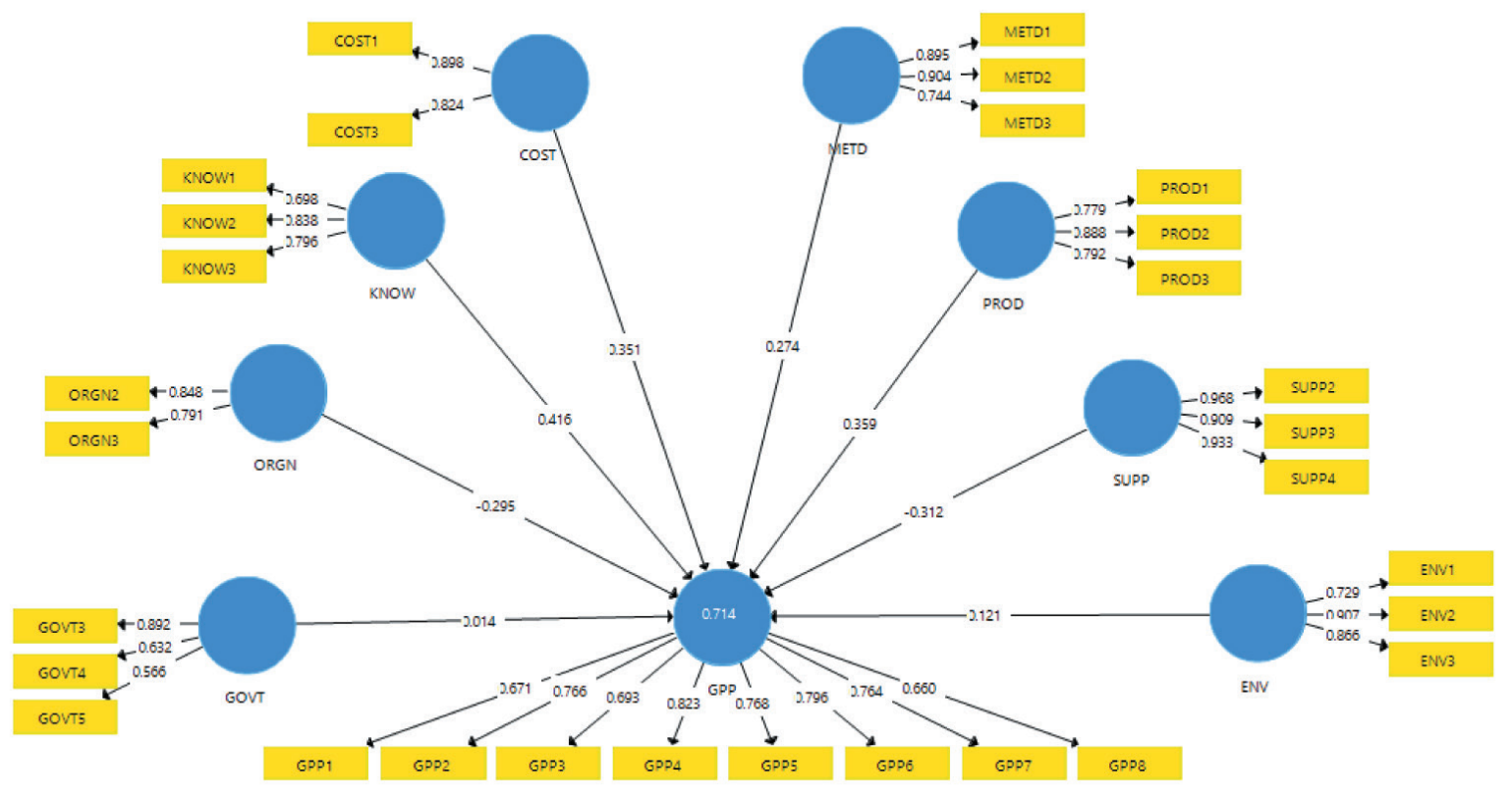

Figure 1. Conceptual Framework Path Diagram

Table 2. Discriminant Validity dan Composite Reliability

\begin{tabular}{lcccc}
\hline Variable & AVE & $\sqrt{A V E}$ & Composite Reliability & Cronbach's Alpha \\
\hline GPP & 0,555 & 0,745 & 0,908 & 0,855 \\
GOVT & 0,505 & 0,711 & 0,746 & 0,655 \\
ORGN & 0,672 & 0,82 & 0,804 & 0,515 \\
KNOW & 0,608 & 0,78 & 0,822 & 0,678 \\
COST & 0,743 & 0,862 & 0,853 & 0,66 \\
METD & 0,724 & 0,851 & 0,886 & 0,813 \\
PROD & 0,674 & 0,821 & 0,861 & 0,756 \\
SUPP & 0,878 & 0,937 & 0,956 & 0,93 \\
ENV & 0,701 & 0,837 & 0,874 & 0,79 \\
\hline
\end{tabular}

From the calculation $(\sqrt{A V E})$ shows that all variables in the model estimated to meet the discriminant validity criteria because the value $\sqrt{A V E}>0.5$. And for calculations, composite reliability shows the value of $\geq 0.6$ and all Cronbach's Alpha $\geq 0.5$. Thus showing that all constructs on the estimated model have high reliability and meet reliable criteria.

After the model meets the outer model criteria, further testing of the inner model is carried out. The inner model is evaluated by looking at the R-Square value [16]. The value of $\mathrm{R}$ Square obtained is 0.714 value was obtained at 0.51 , which means the research model has a predictive relevance value.

Next is the test of the hypothesis to find out the effect of the two variables on the application of GPP. For the hypothesis test, the study used $95 \%$ confidence rating, then a t-table value of 2,042 . If the $\mathrm{t}$ statistical value in the Path Coefficient table is greater than the t-table value, then it can be said that significant variables affect the application of GPP and vice versa. The results of hypothesis testing can be seen in table 3 . 
Table 3. Variable Hypothesis Testing

\begin{tabular}{|c|c|c|c|c|c|}
\hline Variable & Original Sample & Sample Mean & Standard Deviation & t-Statisctics & P Values \\
\hline GOVT GPP $\rightarrow$ & 0,014 & 0,101 & 0,228 & 0,061 & 0,951 \\
\hline ORGN GPP $\rightarrow$ & 0,295 & 0,133 & 0,258 & 1,143 & 0,262 \\
\hline KNOW GPP $\rightarrow$ & 0,416 & 0,415 & 0,338 & 1,231 & 0,228 \\
\hline COST GPP $\rightarrow$ & 0,351 & 0,293 & 0,154 & 2,284 & 0,030 \\
\hline METD GPP $\rightarrow$ & 0,274 & 0,141 & 0,308 & 0,889 & 0,381 \\
\hline PROD GPP $\rightarrow$ & 0,359 & 0,381 & 0,149 & 2,407 & 0,022 \\
\hline SUPP GPP $\rightarrow$ & 0,312 & 0,312 & 0,224 & 0,281 & 0,275 \\
\hline ENV GPP $\rightarrow$ & 0,121 & 0,140 & 0,231 & 0,524 & 0,604 \\
\hline
\end{tabular}

The results of the first, second, third, fifth, seventh, and eighth hypotheses explain that variables GOVT, ORGN, KNOW, METD, SUPP, and ENV variables have an insignificant influence on the application of GPP.

The results of the fourth and sixth hypotheses explained that variable COST and PROD variables have a significant influence on the application of GPP because the value of t-statistics on cost variables are 2.284 and PRODUCT which is 2.407 greater than the value of t-table $(2,042)$.

\section{Discussion}

From the results of this study, it can be said that all eight variables affect the application of GPP. This can be seen from the R-Square value of 0.714, which means that the value indicates that the variables GOVT, ORGN, KNOW, COST, METD, PROD, SUPP, and ENV can explain the GPP application variant of about $71.4 \%$, the rest is influenced by other factors not discussed in the study. Based on hypothesis testing conducted by comparing t-statistical values obtained from resampling bootstrap, with t-table values received variables that have no effect on GPP application variables.

The results of the fourth and sixth hypotheses explained that the COST (Organizational Cost) and PROD variable (Product) have a significant influence on the application of GPP because the value of t-statistics on the COST variable, which is 2.284 , and PRODUCT which is 2.407 greater than the value of t-table (2,042). Variable COST (Organizational Costs) and PROD (Products) significantly affected the implementation of GPP by $35.1 \%$ and $35.9 \%$, respectively.

As for the results of the first hypothesis, second, third, fifth, seventh, and eighth explains that the variables GOVT (Government, LSM, Public), ORGN
(Organization), KNOW (Knowledge), METD (Method), PROD (Product), SUPP (Supplier), and ENV (Environmental Impact) have an insignificant influence on the application of GPP because the tstatistical value is smaller than the value of the t-table. Although there are variables that do not significantly affect the application of GPP, based on the value of Q2 shows that the structure model in this study, overall, is quite significant.

Gunther [17] explains that GPP can contribute to an environmental management approach with ecodesign solutions. Similarly, Karna [18] argues that eco-design aims to avoid or minimize the environment of products throughout its life cycle, such as the selection of substances, materials, and products, the life span of products, products that use low energy and can be recycled. The recommendation of solutions that hospitals can do to implement GPP is a hospital using environmentally friendly products or eco-design. But to provide environmentally friendly products for a hospital agency is still considered difficult and requires a high enough cost, so it requires careful cost planning taking into account the value of the product and the economic life of environmentally friendly products.

According to Deng [19], the Chinese government has recognized that the GPP can make a significant contribution to the national environment and sustainable development by promoting and guiding the selection and purchase of eco-label products. Linda [20] argued that in implementing the GPP in Hong Kong in stores procurement regulations that were amended in 2000 to ask government departments to give consideration as far as possible and where economically rational to buy products by increasing recycling, higher recycled content, greater energy efficiency, and reducing the use of toxic substances.

According to the previous research [19], [20], [21] the recommendations of other solutions are from the government. The government can carry out socializa- 
tion about GPP to the hospital's executive management because it is felt that there are still many who do not understand the GPP. In addition to socialization, it can be done with reward and punishment. With the reward and punishment from the government, the hospital will be encouraged to implement environmentally friendly procurement. The hospital side can also clarify the strategic objectives to implement GPP and prepare a professional workforce. Hospitals can conduct training on environmentally friendly procurement to prepare for the implementation of GPP. Hospitals can conduct comparative studies with other agencies that have implemented GPP.

\section{Conclusion}

This research paper examined the GPP as a tool to achieve environmental policy objectives in procurement activities of goods/services. With the GPP, it is expected that an agency can have a positive impact on the environment. But in Indonesia, it is still not implemented properly and thoroughly, especially in hospital agencies.

This research found that in implementing GPP, several factors make it a challenge for an agency. These factors are the government, the organization, costs, employee knowledge, methods applied, products used, suppliers, and impacts on the environment. Factors that significantly affect the implementation of GPP are the products used and the cost of the organization.

Recommendations for action that need to be done by the government is to socialize about GPP to hospital executive management and by applying rewards and punishments. For hospitals can plan the budget by estimating the costs needed to implement GPP, clarifying the strategic objectives of environmentally friendly procurement, organizing training, and conducting comparative studies with agencies that have implemented GPP. Hopefully, the recommendation of the action can be a consideration for the hospital and can be a reference for the hospital to develop a strategy in the future.

For further research is expected to add the scope of research objects to provide more varied and representative results to the condition of the problem of GPP application in Indonesian hospitals. In addition, further research is expected to add other variables to complement the GPP implementation factor in hospitals.

\section{Funding}

This research was financially supported by The Faculty of Engineering, Diponegoro University, Indonesia through Strategic Research Grant 2021.

\section{References}

[1] D. W. Zulmawan, Pengadaan Berkelanjutan Minim Risiko, Jakarta: Jala Permata Aksara, 2019.

[2] A. Kopp, "Marrakech Task Force on Sustainable Public Procurement led by Switzerland," Swiss Federal Office for the Environment (FOEN), May 2011, Available: https://sustainableprocurement.eu.com/documents/ MTFonSPPReportCSD19FINAL.pdf.

[3] European Commission, Risk Management in the Procurement of Innovation, Brussels: European Commission, 2010.

[4] W. Cheng, A. Apollonia, A. D'Amato and Q. Zhu, "Green Public Procurement: Missing Concepts and Future Trends - A Critical Review," Journal of Cleaner Production, vol. 176, pp. 770-784, 2018, doi: 10.1016/j.jclepro.2017.12.027.

[5] S. Bakir, S. Rahman and S. Khan, "Cognition Map of Environmentally-Oriented Government Procurement: An Application of The Dematel Approach," in 18th International Symposium on Logistics (ISL), Vienna, Austria, 2013, pp. 860-868.

[6] G. Oruezabala and J. Rico, "The Impact of Sustainable Public Procurement on Supplier Management - The Case of French Public Hospital," Industrial Marketing Management, vol. 41, no. 4, pp. 573-580, 2012, doi: 10.1016/j.indmarman.2012.04.004.

[7] P. Bolton, "Protecting the Environment Through Public Procurement: The Case of South Africa," Natural Resources Forum, vol. 32, pp. 1-10, 2008, doi: 10.1111/j.14778947.2008.00171.x.

[8] S. Bakir, S. Khan, K. Ahsan, and S. Rahman, "Exploring the Critical Determinants of Environmentally Oriented Public Procurement Using the DEMATEL Method," Journal of Environmental Management, vol. 225, pp. 325-335, 2018, doi: 10.1016/j.jenvman.2018.07.081.

[9] L. Trisnantoro and E. Listyani, "Jumlah Rumah Sakit di Indonesia," Manajemen Rumah Sakit, 2018. [Online]. Available: https://manajemenrumahsakit.net/2018/04/ jumlah-rumah-sakit-di-indonesia/. [Accessed July 19, 2021].

[10] H. Walker and S. Brammer, "The Relationship Between Sustainable Procurement and e-Procurement in the Public Sector," Int. J. Production Economics, vol. 14, no. 1, pp. 256-268, 2012, doi: 10.1016/j.ijpe.2012.01.008.

[11] K. Ahsan and S. Rahman, "Green Public Procurement Implementation Challenges in Australian Public Healthcare Sector," Journal of Cleaner Production, vol. 152, pp. 181197, 2017, doi: 10.1016/j.jclepro.2017.03.055.

[12] M. Braulio-Gonzalo and M. D. Bovea, "Criteria Analysis of Green Public Procurement in the Spanish Furniture," Journal of Cleaner Production, vol. 258, 120704, 2020, doi: 10.1016/j.jclepro.2020.120704.

[13] I. Ghozali, Structural Equation Modeling, Metode Alternatif dengan Partial Least Square (PLS), Edisi 4. Semarang: Badan Penerbit Universitas Diponegoro, 2014.

[14] I. Ghozali, Structural Equation Modeling Metode Alternatif dengan Partial Least Square (PLS). Semarang: Badan Penerbit Universitas Diponegoro, 2008. 
[15] W. Abdillah and J. Hartono, Konsep dan Aplikasi PLS (Partial Least Square) untuk Penelitian Empiris. Yogyakarta: Badan Penerbit Fakultas Ekonomi dan Bisnis UGM, 2009.

[16] W. Chin, The Partial Least Squares Approach for Structural Equation Modeling. Cleveland, Ohio, 1998.

[17] E. S. Gunther, "The Hurdles Analysis As An Instrument For Improving Environmental Value Chain Management," Progress in Industrial Ecology, vol.2, no. 1, pp.107-131, 2005, doi: 10.1504/PIE.2005.006780.

[18] A. Karna, Environmentally Oriented Product Design. Finland: SET Technology Industries, 2002.

[19] M.D. Mijatovic, O. Uzelac, and A. Stoiljkovic, "Effects of human resources management on the manufacturing firm performance: Sustainable development approach," Int J Ind Eng Manag, vol. 11, no. 3, pp. 205-212, 2020, doi: 10.24867/IJIEM-2020-3-265.

[20] T. Deng, "The development of the Chinese environmental labeling," Economic Observation (in Chinese), vol. 13, no. 4, pp. 23-29, 2006.

[21] L.W. Ho, N.M. Dickinson, and G.Y. Chan, "Green procurement in the asian public sector and the Hong Kong private sector," Natural Resources Forum, vol. 24, no. 1, pp. 24-38, 2010, doi: 10.1111/j.1477-8947.2010.01274.x. 